\title{
Evaluation of serum lipids in preeclampsia: a comparative study
}

\author{
Varija Thathagari, Veerendra Kumar C. M.*
}

Department of Obstetrics and Gynecology, Vijayanagar Institute of Medical Sciences, Ballari, Karnataka, India

Received: 27 February 2018

Accepted: 03 March 2018

\section{*Correspondence:}

Dr. Veerendra Kumar C. M.,

E-mail: veerucm1972@gmail.com

Copyright: (C) the author(s), publisher and licensee Medip Academy. This is an open-access article distributed under the terms of the Creative Commons Attribution Non-Commercial License, which permits unrestricted non-commercial use, distribution, and reproduction in any medium, provided the original work is properly cited.

\section{ABSTRACT}

Background: Preeclampsia occurs in 7 to $10 \%$ of pregnancies worldwide. At present most, popular theory is an oxidative stress. Abnormal lipid profiles and species may have a role in promotion of oxidative stress and vascular dysfunction seen in pre-eclampsia. Objectives of this study was carried out to evaluate lipid profile in subjects with preeclampsia and to compare lipid profile in subjects of preeclampsia as compared to normal pregnant women.

Methods: A comparative longitudinal study was conducted under the tertiary care hospital setting over a period of one year where 440 study subjects were enrolled out of which 220 subjects were pre-eclamptic and 220 subjects were normotensive with gestation of 28 weeks to till term. Lipid profiling was done in all the subjects.

Results: The mean serum levels of total cholesterol (198.5 \pm 18.91$)$, HDL (50.63 \pm 9.35$)$, LDL (84.5 \pm 16.16$)$, VLDL $(42.75 \pm 4.72)$ and TGA $(74.92 \pm 11.95)$ were higher in pre-eclampsia group compared to normotensive group and this difference in the levels of lipid parameters was found to be statistically significant.

Conclusions: Dyslipidemia is significantly evident in preeclampsia and plays an important role in its pathogenesis.

Keywords: Lipid profile, Preeclampsia, Triglycerides, Total Cholesterol

\section{INTRODUCTION}

Preeclampsia is one of the most common complications of pregnancy and is a leading cause of maternal and perinatal morbidity and mortality. ${ }^{1}$ Preeclampsia occurs in $7-10 \%$ of pregnancies worldwide. ${ }^{2}$

Raised blood pressure is present in $5 \%$ of entire pregnancies, in $10 \%$ of primi parous women and $20-25 \%$ of women with previous history of chronic hypertension. ${ }^{3}$ With increasing age, the risk of developing $\mathrm{PIH}$ increases. ${ }^{4}$ Women with PIH are more likely to develop overweight, dyslipidemia. ${ }^{5}$ Insulin resistance and endothelial dysfunction are independent risk factors for cardiovascular disease. $^{6}$

The etiology of preeclampsia is still unknown. The hypotheses currently accepted are the placental ischemia hypothesis, genetic hypothesis, the immune maladaptation and hypothesis of the imbalance between free oxygen radicals and scavengers in favour of oxidants. At present the most popular theory is an oxidative stress. Abnormal lipid profiles and species may have a role in promotion of oxidative stress and vascular dysfunction seen in preeclampsia. ${ }^{7}$

Predominantly the atherogenic small low-density lipoproteins (LDL) and the Vascular Cell Adhesion Molecules (VCAM) are increased in association with hyperlipidaemia in preeclampsia. Although there is growing evidence indicating that the risk of preeclampsia is increased in women with elevated levels of oxidized low-density lipoproteins and triglycerides. ${ }^{8}$ The causal relationship of lipid peroxidation in the pathogenesis of pre-eclampsia is not clear. 
During pregnancy, the increased level of estrogen causes increased hepatic biosynthesis of endogenous triglycerides through VLDL, this process is modulated by hyperinsulinism that starts in pregnancy and may result in endothelial cell damage in pregnancy. ${ }^{9}$ In Preeclampsia, serum triglyceride concentration increases much more notably, two to three times more and the triglycerides are likely to be accumulated in vessels like uterine spiral arteries and contribute to endothelial damage by generating small, dense LDL particles. ${ }^{10}$

Aims and objectives of this study were to evaluate lipid profile in patients with preeclampsia and to compare lipid profile in patients of preeclampsia as compared to normal pregnant women from 28 weeks of gestation till term.

\section{METHODS}

\section{Study design, study setting and duration}

It is cross-sectional comparative study conducted under the setting of tertiary care hospital in the department of OBG, Vijayanagar Institute of Medical Sciences (VIMS), Ballari during the year 2015 .

\section{Sample size}

To determine the appropriate sample size for detecting a difference of at least $10 \mathrm{mg} / \mathrm{dl}$ total cholesterol levels between the means of two samples, at $95 \%$ confidence intervals with a power of 80 , the sample size was worked to be 157 in each group. In this study a total 220 patients in each group were enrolled for the study based on the inclusion criteria.

\section{Inclusion criteria}

Out patients and inpatients attending and admitted in OBG department were enrolled for the study after explaining about the study and taking informed consent.

- Group A: Pregnant women with pre-eclampsia between 28 weeks-till term.

- Group B: Pregnant women with pregnancy between 28 weeks till term without preeclampsia.

\section{Exclusion criteria}

Pregnant women with other medical co morbid conditions were excluded from the study.

\section{Investigations}

After following proper aseptic precautions, $5 \mathrm{ml}$ venous blood sample was withdrawn from all subjects and transported as per the proper laboratory procedures. The sample was allowed to clot, and serum was separated in biochemistry lab. Serum was processed to obtain values of total cholesterol, HDL, VLDL, LDL, Triglycerides.
Data variables: Socio-demographic variables, obstetric variables and lipid parameters were collected from the reports of the study subjects.

\section{Statistical analysis}

All the collected data was entered into an excel sheet and after appropriate data cleaning, the data was transferred and analyzed using SPSS software version 22. Appropriate descriptive statistics like percentages and mean, standard deviation is used to describe the data variables. The difference in the means of lipid parameters among the two groups was tested using t test and a $\mathrm{P}$ value of less than 0.05 was considered to be statistically significant.

\section{RESULTS}

During the study period of one year, a total of 440 pregnant mothers were studied, out of which half of them were normotensive and another half were pre-eclamptic cases.

Table 1: Age wise distribution of the study subjects among the two groups.

\begin{tabular}{|lll|}
\hline Age (years) & $\begin{array}{l}\text { Normal group } \\
\mathrm{N}=220\end{array}$ & $\begin{array}{l}\text { Pre-eclampsia } \\
\text { group } \mathrm{N}=220\end{array}$ \\
\hline $18-25$ & $140(63.6 \%)$ & $110(50.0 \%)$ \\
\hline $26-30$ & $56(25.5 \%)$ & $64(29.1 \%)$ \\
\hline $31-35$ & $24(10.9 \%)$ & $46(20.9 \%)$ \\
\hline
\end{tabular}

Table 2: Obstetric history of the study subjects among the two groups.

\begin{tabular}{|lll|}
\hline $\begin{array}{l}\text { Obstetric } \\
\text { history }\end{array}$ & $\begin{array}{l}\text { Normal Group } \\
\text { N=220 }\end{array}$ & $\begin{array}{l}\text { Pre-eclampsia } \\
\text { Group N=220 }\end{array}$ \\
\hline Primi gravida & $120(54.5 \%)$ & $144(65.5 \%)$ \\
\hline multigravida & $100(45.5 \%)$ & $76(34.5 \%)$ \\
\hline
\end{tabular}

Table 3: Lipid profile of the study subjects among the two groups.

\begin{tabular}{|llll|}
\hline Parameters & $\begin{array}{l}\text { Normal } \\
\text { group } \\
\text { Mean } \pm \text { SD }\end{array}$ & $\begin{array}{l}\text { Pre- } \\
\text { eclampsia } \\
\text { group } \\
\text { Mean } \pm \text { SD }\end{array}$ & P value \\
\hline $\begin{array}{l}\text { Total } \\
\text { Cholesterol }\end{array}$ & $136.54 \pm 15.22$ & $198.5 \pm 18.91$ & $<0.01$ \\
\hline $\begin{array}{l}\text { HDL } \\
(\mathrm{mg} / \mathrm{dl})\end{array}$ & $48.63 \pm 8.20$ & $50.63 \pm 9.35$ & 0.013 \\
\hline $\begin{array}{l}\mathrm{LDL} \\
(\mathrm{mg} / \mathrm{dl})\end{array}$ & $70.7 \pm 11.45$ & $84.5 \pm 16.16$ & $<0.01$ \\
\hline $\begin{array}{l}\text { VLDL } \\
(\mathrm{mg} / \mathrm{dl})\end{array}$ & $22.75 \pm 3.42$ & $42.75 \pm 4.72$ & $<0.01$ \\
\hline $\begin{array}{l}\text { Triglyceride } \\
(\mathrm{mg} / \mathrm{dl})\end{array}$ & $62.23 \pm 10.02$ & $74.92 \pm 11.95$ & $<0.01$ \\
\hline
\end{tabular}


In both the groups half of the pregnant women were in the age group of 18-25 years. Both groups were comparable with respect to age distribution and there was no statistically significant difference in the age distribution of the study subjects among the two groups. The primi gravida were comparatively more in Preeclampsia group $(65 \%)$ and multi gravida were comparatively more in normotensive group $45 \%$.

The proportion of pregnant women with dyslipidaemia was more among the Pre-eclampsia group and it was observed that the mean serum levels of total cholesterol (198.5 \pm 18.91$)$, HDL (50.63 \pm 9.35$)$, LDL (84.5 \pm 16.16$)$, VLDL (42.75 \pm 4.72$)$ and TGA (74.92 \pm 11.95$)$ were higher in Pre-eclampsia group compared to Normotensive group and this difference in the levels of lipid parameters was found to be statistically significant.

Among all the parameters, the difference in total cholesterol levels among the two groups were very high (mean difference $62 \mathrm{mg} / \mathrm{dl}$ ) followed by VLDL (22mg/dl), LDL $(14 \mathrm{mg} / \mathrm{dl})$ and TGA $(12 \mathrm{mg} / \mathrm{dl})$. However, the difference in the HDL levels among the two groups was less compared other lipid parameters.

\section{DISCUSSION}

In the present study, author investigated the role of lipid profile in preeclampsia. Author used normotensive pregnant women as a control group, whereas, hypertensive pregnant women as test group. In the present study, serum levels of TC, TGs, LDL and VLDL were significantly increased in hypertensive pregnant women. PIH is known to be associated with hypertriglyceridemia. The main factor behind hypertriglyceridemia is estrogen. In pregnancy there is increase in estrogen levels. Estrogen induces hepatic production of TGs that causes PIH and endothelial dysfunction through the generation of LDL and VLDL.

Anjum et al conducted a comparative trial on analysis of serum lipid profile between normotensive and hypertensive pregnant women at Jinnah Hospital in Lahore, Pakistan during September 2012 to March 2013. ${ }^{11}$ In hypertensive pregnant women, the serum levels of TC, TGs, LDL and VLDL were significantly high $(\mathrm{p}<0.05)$ whereas, the serum level of HDL was significantly low $(\mathrm{p}<0.05)$ when directly compared with that of normotensive pregnant women.

Mikhail et al described that increased serum triglyceride levels leads to its increased endothelial accumulation, which may result in endothelial dysfunction in pregnancy. ${ }^{12}$ Increased triglycerides in pre-eclampsia are likely to be deposited in uterine spiral arteries and contribute to the endothelial dysfunction, both directly and indirectly through generation of small, dense LDL.

Gohil et al quoted that dyslipidemia in the form of significantly decreased HDL concentration and significantly increased total cholesterol, LDL, VLDL and Triglycerides concentration is conspicuously evident in subjects of preeclampsia as compared to non-pregnant, normotensive pregnant and postpartum subjects. ${ }^{13}$

Enquobahrie et al assessed serum lipid levels in 57 patients with pre-eclampsia and 510 pregnant women in the control group and they found significantly higher levels of triglycerides in pre-eclampsia. ${ }^{14}$

Deshpande $\mathrm{H}$ et al were reported cholesterol, LDL, VLDL and triglyceride levels were gradually increasing from Mild PIH to Severe PIH to Eclampsia, while HDL levels were gradually decreasing from Mild PIH to Severe PIH to Eclampsia. ${ }^{15}$

Study conducted by Kashinakunti et al concludes that there is a positive correlation between serum triglycerides and systolic blood pressure and diastolic blood pressure in preeclampsia cases. ${ }^{7}$ Elevated maternal triglyceride levels measured during early pregnancy are associated with pregnancy complications and adverse pregnancy outcomes. These results suggest that future lifestyle programs in women of reproductive age with a focus on lowering triglyceride levels (i.e. Diet, weight reduction, and physical activity) may help to prevent hypertensive complications during pregnancy and adverse birth outcomes.

\section{CONCLUSION}

Author conclude that there is elevation of serum lipids among preeclamptic when compared to normal pregnancy. Estimating serum lipid profile is a simple screening test, helps to recognize dyslipidaemia in early second trimester of patients who are at risk of preeclampsia. Due to early detection of altered lipid profile in preeclamptic, incidence of complications can be decreased, which in turn reduce the materno-fetal morbidity and mortality.

\section{ACKNOWLEDGMENTS}

Authors would like to thank the family members of the patients for their co-operation and support for the smooth conduct of the study. The authors thank Dr. Suman Gaddi, Professor and Head for facilitating the study.

Funding: No funding sources

Conflict of interest: None declared

Ethical approval: The study was approved by the Institutional Ethics Committee

\section{REFERENCES}

1. Vanderjagt DJ. HDL and homocysteine levels correlate inversely in preeclamptics women in North Nigeria. Acta Obstet Gynecol Scand. 2004;83:53642 . 
2. Mutlu-Turkoglu U, Ademoglu E. Imbalance between lipid peroxidation, antioxidant status in preeclampsia. Gynecol Obstet Invest. 1998;46:37-40.

3. Ghosh MK. Maternal mortality: a global perspective. J Reprod Med. 2001;46(5):427-33.

4. Zhang J. Partner change, birth interval and risk of pre-eclampsia: a paradoxical triangle. Paediatr Perinat Epidemiol. 2007;21:31-5.

5. Belo L, Caslake M, Gaffney D, Santos-Silva A, Pereira-Leite L, Quintanilha A, et al. Changes in LDL size and HDL concentration in normal and preeclamptic pregnancies. Atherosclerosis. 2002;162(2):425-32.

6. Seely EW, Solomon CG. Insulin resistance and its potential role in pregnancy-induced hypertension. $\mathrm{J}$ Clin Endocrinol Metab. 2003;88(6):2393-8.

7. Kshinakunti SV, Sunitha H, Gurupaddappa K, Manjula R. Lipid Profile In Preeclampsia-Case Control Study. Journal of Clinical and Diagnostic Research. 2010;4:2748-51.

8. Qiu C, Phung TT, Vadachkoria T. Oxidised low densitylipoprotein and the risk of Preeclampsia. Physiol Res. 2005.

9. Isomaa B, Almgren P, Tuomi T, Forsen B, Lahti K, Nissen $M$, et al. Cardiovascular morbidity and mortality associated with the metabolic syndrome. Diabetes Care. 2001;24(4):683-9.

10. Girman CJ, Rhodes T, Mercuri M, Pyorala K, Kjekshus J, Pedersen TR, et al. The metabolic syndrome and risk of major coronary events in the scandinavian simvastatin survival study $(4 \mathrm{~S})$ and the Air Force/Texas Coronary Atherosclerosis Prevention Study (AFCAPS/TexCAPS). Am J Cardiol. 2004;93(2):136-41.

11. Anjum R, Zahra N, Rehman K, Alam R, Parveen A, et al. Comparative analysis of serum lipid profile between normotensive and hypertensive Pakistani pregnant women. J Mol Genet Med. 2013;7:64.

12. Mikhail MS, Basu J, Palan PR, Furgiuele J, Romney SL, Anyaegbunam A. Lipid profile in women with preeclampsia: relationship between plasma triglyceride levels and severity of preeclampsia. Journal of the Association for Academic Minority Physicians: the official publication of the Association for Academic Minority Physicians. 1995;6(1):43-5.

13. Gohil JT, Patel PK, Priyanka G. Lipid profile in patients of preeclampsia. Journal of Obstetrics and Gynecology of India. 2011;61(4):399-403.

14. Enquobahrie DA, Williams MA, Butler CL, Frederick IO, Miller RS, et al. Maternal plasma lipid concentrations in early pregnancy and risk of preeclampsia. Am J Hypertens. 2004;17:574-81.

15. De J, Mukhopadhyay A, Saha PK. Study of serum lipid profile in pregnancy induced hypertension. Indian J Clin Biochem. 2006 Sep 1;21(2):165.

Cite this article as: Thathagari V, Kumar VCM. Evaluation of serum lipids in preeclampsia: a comparative study. Int J Reprod Contracept Obstet Gynecol 2018;7:1372-5. 